\title{
Jeoturizm Kapsamında Safranbolu'da Coğrafi Kaynakların Değerlendirilmesi ve Safranbolu Jeoturizm Potansiyelinin Belirlenmesi
}

\author{
Oğuz Dikera*, Taşkın Deniz ${ }^{\mathrm{b}}$, Adnan Çetinkayac \\ aÇanakkale Onsekiz Mart Üniversitesi, Çanakkale. \\ b, Karabük Üniversitesi Safranbolu Meslek Yüksekokulu, Karabük.
}

\section{$\ddot{O} z$}

Jeolojik çeşitlilik bir coğrafi alanın doğal yapısı, kimliği ve kültürü hakkında bilgi veren temel unsurlardandır. Jeolojik kaynakların bulunduğu alanlar ziyaretçiler için doğal açı hava müzesi formundadır. Son yillarda turizm talebi içerisindeki payı artan jeoturizm, jeolojik kaynaklara sahip alanlara yönelik seyahatleri içeren bir turizm tipidir. Bu çalışmanın temel amacı da, jeoturizm kavramının ortaya konulması ile jeolojik çeşitliliğe sahip Safranbolu destinasyonunun coğrafi kaynaklarının jeoturizm açısından değerlendirilmesi ve potansiyelinin belirlenmesidir. Bu bağlamda Safranbolu'da jeoturizm faaliyetleri için uygun dört kanyon, bir nehir vadisi, karstik şekillere sahip bir mağara, dağlık saha ve kayalıklardan teşekkül yer şekilleri tespit edilmiştir. Diğer yandan yapılan SWOT analizleri neticesinde Safranbolu sahasinun hâlihazırda turizm altyapısının bulunması, bilinir olması, coğrafi konumunun merkezi olması, zengin kültürel mirasa ev sahipliği yapması gibi birçok güçlü yönünün yanında jeoturizm arzının bölge için yeni olması, rekabetin bulunmaması, bitki örtüsü bakımından sahip olduğu zenginlik gibi firsatlara ev sahipliği yaptığı belirlenmiştir. Araştırma sonucuna göre Safranbolu arazisinin birçok açıdan jeoturizme uygun olduğu tespit edilmiştir.

Anahtar Kelimeler: Jeolojik Çeşitlilik, Jeolojik Kaynaklar, Safranbolu, Jeoturizm

\section{Conformity Evaluation of Geographical Resources in Safranbolu and Determination of Safranbolu Tourism Destination's Geotourism Potential}

\begin{abstract}
Geological diversity is one of the main factors that inform about a geographical area's natural structure, identity and culture. Geological provinces are in the form of natural open air museum for visitors. Geotourism as a tourism type, based on travels to geological areas had been increased its market share in recent years. The main purpose of this work is evaluation of geographical resources of Safranbolu destination about jeotourism potential which have geological diversity. In this context, within the scope of this research there are four canyons, one cave with karst landforms, one river valley, mountainous terrain and rupicolous landforms are determined which are eligible for geotuourism activities. On the other hand, according to SWOT analysis' results, strengths such as current tourism infrastructure, identifiability, geographical location, cultural wealth, opportunities such as lack of competition in goetourism market, plant diversity are determined for Safranbolu. According to results, Safranbolu destination is determined eligible for geotourism activities.
\end{abstract}

Keywords: Geological Diversity, Geological Resources, Safranbolu, Geotourism 


\section{GíRiş}

Serbest zamanların artması ve gelişen teknoloji ile merak unsurunun insanları farklı arayışlara yöneltmesi sonucunda turizm ve tiplerine olan talep artmıştır. Özellikle II. Dünya Savaşı'ndan sonra etkisini arttıran sivil havacılığın da katkısıyla seyahat süreleri kısalmış ve insanlar uzun mesafelere kısa sürelerde ulaşabilir hale gelmiştir. $\mathrm{Bu}$ ise çok farklı güdüler ile yapılacak seyahatleri kolaylaştırmıştır. $\mathrm{Bu}$ güdülerin başında yeryüzünün ve doğanın gelişimini anlama ve öğrenme gelmektedir. Doğal ortamların oluşumu ile ilgili birer açık hava müzesi niteliğindeki jeolojik miras alanlarının da popülerliği bu bağlamda artış göstermiştir. Bu bilgiler ışığında jeolojik miras, bu miras kapsamında oluşturulan jeoparklar ve jeoparklara düzenlenen turlar ile oluşmuş jeoturizm kavramlarının araştırılması, ortaya konulması ve potansiyeli olan bölgelerin belirlenmesi önem taşımaktadır.

Bir bölgenin jeolojik mirası aynı zamanda o bölgenin kültürel mirası konumundadır. Bölgenin fiziki anlamda oluşumu, gelişimi, bölgede yaşamış ve yaşamakta olan canlı çeşitliliği, geçmişte yaşanan doğa olayları gibi birçok unsur hakkında bilgi jeolojik ve jeomorfolojik kaynaklardan edinilmektedir. Söz konusu kaynaklar üzerindeki en önemli sorun bu alanların önemlerini yitirip yok olmasıdır. Jeoparkların önemi jeolojik, jeomorfolojik ve coğrafi zenginliğin korunması ve gelecek nesillere aktarılması noktasında ortaya çıkmaktadır. Jeoturizm, jeolojik mirasın korunması adına projelerinin geliştirilmesi ve gelecek kuşaklara aktarılmasında önemli bir unsurdur. Diğer yandan jeoturizm, turistik ürünün çeşitlenmesine ve yeni iş kollarının gelişimine de katkı sağlamaktadır.

Bu bağlamda çalışmanın amacı, kültür ağırlıklı turizm talebi olan Safranbolu destinasyonunun coğrafi kaynaklarının jeoturizm açısından değerlendirilmesi ve Safranbolu'nun jeoturizm potansiyelinin belirlenmesidir. Çalışma, Safranbolu'da jeolojik ve jeomorfolojik yapının, doğal çeşitliliğin ve jeolojik kimliğin gelecek kuşaklara aktarılması ve turizm talebinin çeşitlenmesi noktasında önem taşımaktadır.

Araştırma konusu ile ilgili literatür sınırlıdır. Literatürdeki çalışmalarda konu turizm perspektifinden değil jeoloji ve peyzaj mimarlığı gibi bilim dalları açısından ele alınmıştır. Bu çalışmada ise jeoturizm ve jeolojik miraslar, turizm coğrafyası kapsamında değerlendirilmiştir. Araştırma kapsamında Karabük ili Safranbolu ilçesinin jeolojik, jeomorfolojik ve coğrafi zenginlikleri değerlendirilmiş ve sahanın jeoturizm potansiyeli, turizm perspektifinden değerlendirilerek sonuçları ortaya konulmuştur.

\section{Jeoturizm Kavramı}

Sürekli büyüyen turizm pazarında talep farklı noktalara yönelmektedir. Özellikle insanların rutin faaliyetleri dışında kalan serbest zamanlarının çoğalması tatil için ayrılan sürenin uzaması sonucunu doğurmuştur. Bu bağlamda önceleri yalnızca tatil için gerçekleştirilen seyahatlerde değişik güdüler ön plana çıkmış, böylece farklı turizm tipleri oluşmuştur. Söz konusu güdüler sonucunda oluşan turizm tiplerinden birisi de ekoturizm olarak karşımıza çıkmaktadır. 
Ekoturizm; doğa ile ilgili araştırma yapma, doğal oluşumlara ilgi duyma, canlı türlerini gözlemleme gibi belirli amaçlarlar ile bozulmamış ve yıpratılmamış doğal alanlara gerçekleştirilen seyahatlerin genel adıdır (Orams, 1995: 3). Bir başka tanımla ekoturizm; doğal ve kültürel miras konulu, ziyaretçi ve yerel halkın menfaatlerini gözeten, korumacı ve eğitsel sürdürülebilir turizm faaliyetleridir (Turoğlu ve Özdemir, 2005: 100).

Tanımlardan da anlaşıldığı üzere ekoturizm çevrenin kullanımı açısından bilinçli, toplumsal yönden sorumlu ve ekonomik açıdan verimli bir turizm yaklaşımıdır (Koçan, 2012: 71). Sürdürülebilir turizm tiplerinden biri olan ekoturizm, doğal çevrenin kitle turizminin etkilerinden korunması noktasında farkındalık yaratan ve koruma önlemleri geliştiren bir türdür (Buckley, 2003: 77-78). Bunun ötesinde son yıllarda yapılan çalışmalarda bir doğal alanın yapısının korunmasının ötesinde doğal, peyzaj ve beşeri değerlerin tümünün korunması ile ilgili jeoturizm olgusu geliştirilmiştir (Gümüş, 2008: 28).

Literatürde ekoturizm ya da doğa turizmi kapsamında değerlendirilmesine rağmen jeoturizm, kapsam ve odak noktası ile ilgili turizm tiplerinden farklılaşmaktadır (Kim vd., 2008: 299). Jeoturizm, doğrudan jeolojik ve coğrafi sisteme odaklanarak jeoloji ve coğrafya temelli faaliyetler ile bu faaliyetlere ilgi duyan ziyaretçileri kapsamına almaktadır (Newsome vd., 2012: 19) (Şekil 1). Jeoturizm bölgenin coğrafi karakterini, çevresini, kültürünü ve kültürel mirasını koruyan, diğer yandan yerel halkı göz ardı etmeyen bir turizm tipidir (Heggie, 2009: 257). Jeoturizm, kültürel ve doğal çevreyi bir bütün görerek turizmin yerel halkın yaşam düzeyine olan etkilerini önemser (Gümüş, 2008: 29).

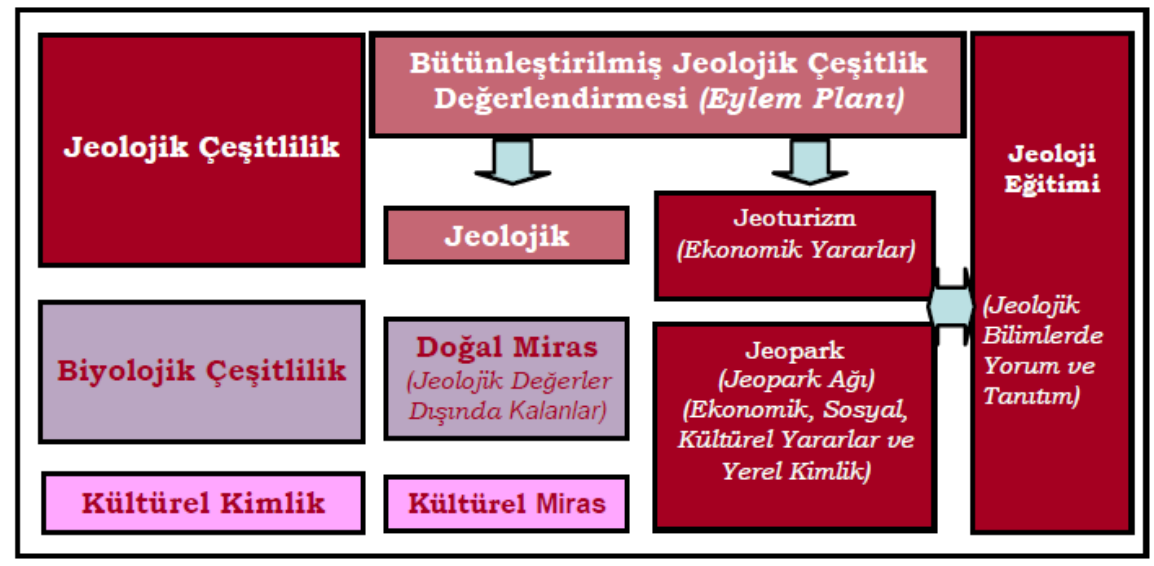

Şekil 1. Jeoturizm Kapsamı ve Odak Noktası

Kaynak: Koçan, 2011: 48

Jeolojik ve jeomorfolojik etken ve süreçlerle gelişmiş, yerkabuğunun evrimini anlatan, doğada çok ender bulunan ve görsel güzelliği olan şekil ve yapıları barındıran sahaların popülerliği artmıştır (Yıldırım ve Koçan, 2008: 138). Bu bağlamda jeoturizm kavramı da önem kazanmıştır. Jeoturizm ile birlikte önem kazanan bir başka kavram da jeoparklardır (Gray, 2008: 288). Jeoparklar aynı veya farklı türden jeositlerin topluca 
bulunduğu, içinde değişik ekosistem, biyolojik varlıklar ve yerel halkın yer aldığı, yaya gezme mesafesinden küçük olmayan alanlardır (Gürsay ve Güneş, 2014: 205).

Jeopark; doğal ve jeolojik güzelliklerin korunması, gelecek nesillere aktarılması ve jeoturizm yolu ile yaşadığımız dünyanın geçmişinin öğrenilmesi amacını taşır (Kızılcahamam Belediyesi, 2013: 2). Yeni bir doğa koruma kavramı olan jeoparklar, 2000 yılında Avrupa Jeoparklar Ağı'nın kurulmasıyla vücut bulmuştur ve entegre bir yapı kazanmıştır. 2015 yılı sonu itibariyle dünya genelinde 32 ülkede 111 jeopark bulunmaktadır. Ülkemizde Küresel Jeopark Ağı (GGN) içerisinde yer alan tek jeopark, Kula Jeoparkı'dır (UNESCO, 2015:2). Ankara ili Kızılcahamam ilçesi sınırları içerisinde bulunan Kızılcahamam Jeoparkı ise GGN'e dâhil olmamasına karşın ulusal ve uluslararası düzeyde tanınırlığı bulunan bir jeoparktır.

Belirtilen jeoparklar haricinde ülkemiz sınırları içerisinde jeoturizm kapsamında jeopark olarak ifade edilebilecek birçok jeolojik ve jeomorfolojik alan bulunmaktadır. Bu bağlamda söz konusu alanların envanterinin belirlenmesi ve jeoturizm kapsamında değerlendirilmesi ile ilgili çalışmaların yapılması; ilgili alanların korunması, sürdürülebilirliğinin sağlanması, turizmin çeşitlenmesi ve yeni istihdam olanakları sağlanması adına önemlidir.

\section{Safranbolu'da Coğrafi Kaynakların Jeoturizm Açısından Değerlendirilmesi}

Bir bölgedeki coğrafi kaynakların jeoturizm kapsamında ve jeopark alanları içerisinde değerlendirilmesi için öncelikle kaynakların taşıması gereken özelliklerin ifade edilmesi gerekmektedir. Literatürde jeoturizm kapsamında değerlendirilecek coğrafi kaynaklar noktasında benzer görüşler bulunmaktadır (Tablo 1).

Jeoturizm ve jeopark kapsamında; jeolojik ve jeomorfolojik özelliğe sahip, kültürel değer taşıyan, estetik açıdan kıymeti bulunan kaynakların değerlendirilmesi konusunda literatürde ağırlıklı görüş birliği oluşmuştur (Ör; Newsome vd., 2012; Dowling, 2011; Filho vd., 2015; Heggie, 2009; Kim vd., 2008, Stueve, vd., 2002; Koçan, 2011). 
Tablo 1. Jeoturizm ve Jeoparklar Kapsamında Değerlendirilen Coğrafi Kaynaklar

\begin{tabular}{|c|c|c|c|}
\hline Temel Kategori & Örnek Jeositler & Temel Kategori & Örnek Jeositler \\
\hline Peyzajlar & Valensole Platosu, Fransa & Rüzgâr Yer Şekilleri & Charamel Bazalt, Morityus \\
\hline Kiyılar & $\begin{array}{l}\text { Büyük Okyanus Yolu, } \\
\text { Avusturalya }\end{array}$ & $\begin{array}{l}\text { Çökelme ile oluşan Yer } \\
\text { Şekilleri }\end{array}$ & Clew Bay Drumlin, İrlanda \\
\hline Dağ Sıraları & Himalayalar, Nepal & Volkanik Yer Şekilleri & $\begin{array}{l}\text { Undara Lava Tüneli, } \\
\text { Avusturya }\end{array}$ \\
\hline Kanyonlar & $\begin{array}{l}\text { Büyük Kanyon, Arizona, } \\
\text { Amerika }\end{array}$ & Kaya Mostrası & Bradgate Park1, İngiltere \\
\hline Nehir Vadileri & Hunza Vadisi, Pakistan & Fosiller & Lyme Regis, İngiltere \\
\hline Buzul Yapılar & $\begin{array}{l}\text { Nigardsbreen Buzulu, } \\
\text { Norveç }\end{array}$ & Şelaleler & Boseong, Güney Kore \\
\hline Kumul Yapılar & $\begin{array}{l}\text { Ash Sharqiyyah Kumsalı, } \\
\text { Umman }\end{array}$ & Mağaralar & Niah Mağarası, Malezya \\
\hline Karstik Şekiller & Mulu Ulusal Parkı, Malezya & Dağlar & \begin{tabular}{|l|} 
Kilimanjaro Dağı, \\
Tanzanya
\end{tabular} \\
\hline Volkanlar & Bromo Dağı, Endonezya & Yer Şekilleri & $\begin{array}{l}\text { Zhangjiajie Milli Jeoparkı, } \\
\text { Çin }\end{array}$ \\
\hline
\end{tabular}

Kaynak: Newsome vd., 2012: 20.

Tablo 1'de belirtilen coğrafi kaynakların benzerleri, bu çalışma kapsamında araştırma sahasında değerlendirilmiştir. Araştırma sahasını oluşturan Safranbolu Platosu'nun güneyi Araç Çayı tarafından çevrelenmiştir. Ilgaz Dağları'nın batı uzantısının kuzey yamaçlarından doğan küçük derelerin birleşmesiyle ortaya çıkan Araç Çayı, plato sahasına Araç ilçesine bağlı Kayabaşı Köyü yakınlarında girmekte ve Safranbolu'ya bağlı Bostanbükü Köyü civarında terk etmektedir. Safranbolu Platosu'nun batısı Sarıçiçek Dağları tarafından kuşatılmıştır. Ahmetusta Geçidi (1080 m) yakınlarında kuzeydoğuya yönelen sınır, 1000 m'nin üzerindeki tepelik alanları (Kumluk Tepe 1159 m, Dağtürbe Tepe 1011 m, Havala Tepe 1168 m gibi) takip eder. Platonun kuzeyi de bir yay şeklinde uzanan tepelik alanlarla çevrilidir. Kızılgüney Tepe (1178 m), Kuzlukbaşı Tepe (1168 m), Kuzbaşı Tepe (1100 m), ÇaIca Tepe (1186 m) ve Meydan Tepe (1246 m), araştırma sahasının kuzeyini oluşturan sınırının en önemli tepeleridir. Safranbolu Platosu'nun doğu sınırı ise, Araç Çayı'na kuzeyden katılan Karadere Vadisi'ni takip eder. Karadere, Ça1ca Tepe'nin güney yamaçlarından Gökveren Dere adı ile kaynağını alır ve Karlı Köyü'nün kuzeybatısından itibaren sahaya girer. Alpagut, Çalcakuzu ve Gökgöz derelerini de toplayarak, Kayabaşı köyü yakınlarında yaklaşık 45 km'lik bir güzergâh sonunda Araç çayına katılır (Şekil 3) (Özdemir ve diğerleri, 2002: 135-136). Safranbolu, karasal iklim ve Karadeniz ikliminin karşılaşma sahasında bulunması sebebi ile iklim çeşitliliğine bağlı olarak flora ve fauna açısından zengindir. 


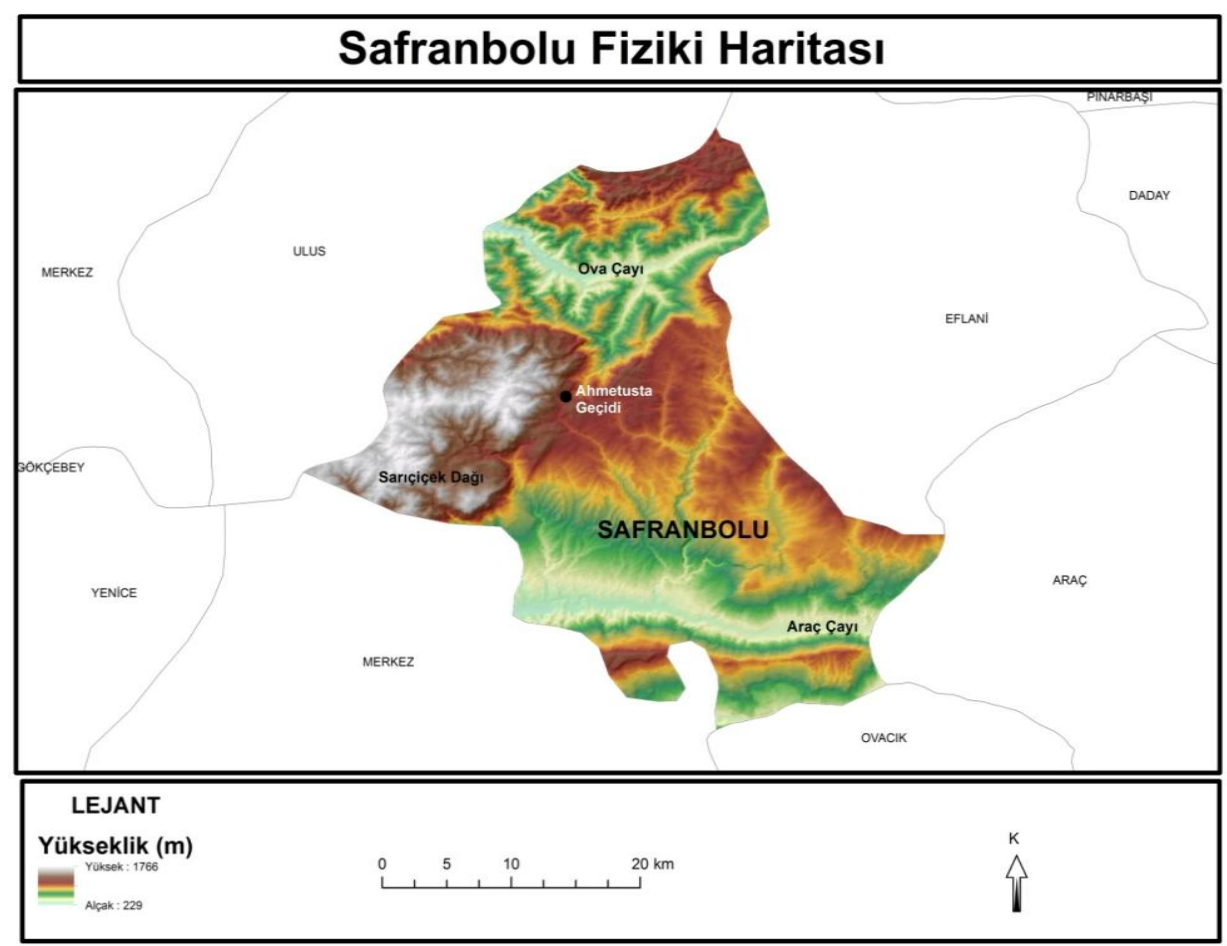

Şekil 2. Safranbolu Fiziki Haritası

Safranbolu ve çevresi, kısmen 2. Zamana (Mezozoik) ait kretase devri ve genel itibariyle 3. Zamana (Senozoik) ait Tersiyer devri eosen ve paleosen ile yer yer pliosen dönemlerine ait tabakaların orojenik faaliyetler sonucunda yükselmesiyle oluşmuştur. Bu özellik bölgede kısa mesafeler içerisinde büyük yükselti farklarının bulunmasına sebep olmuştur. Sahanın en alçak noktasının rakımı 300 m iken en yüksek noktası 1750 m ile Sarı Çiçek Tepesi' dir. Yaklaşık 1500 m'lik yükselti farkı içerisinde genel itibari ile 500-600 m yükseltiye sahip bir plato özelliği taşıyan Safranbolu'daki en önemli yer şekillerini tepeler, kanyon vadiler ve mağaralar oluşturmaktadır (Şekil 4).

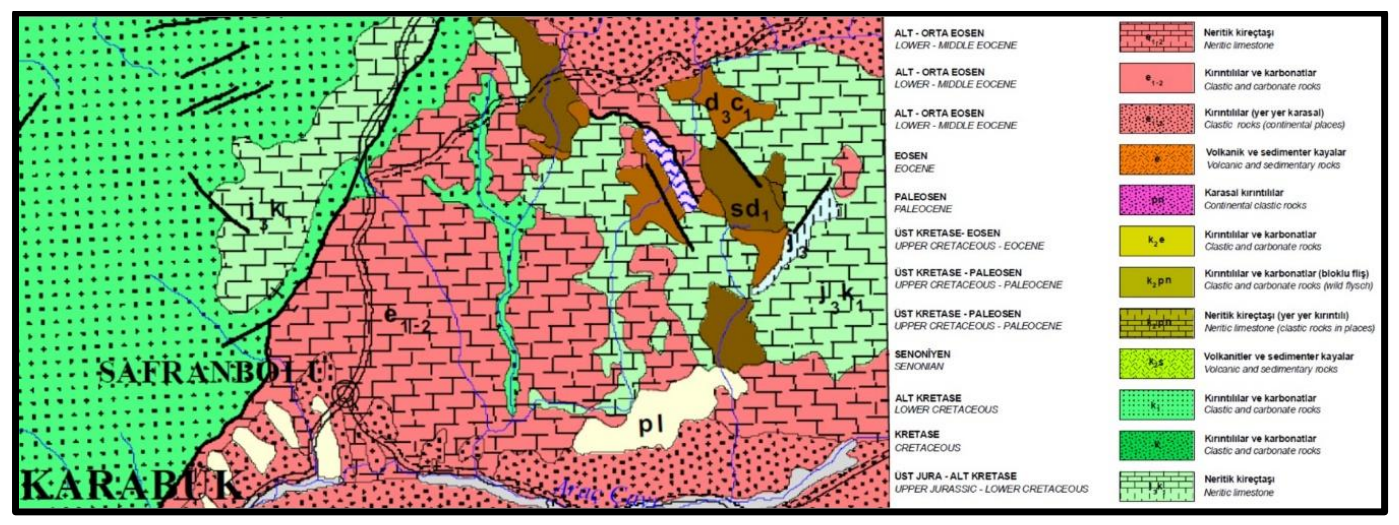

Şekil 3. Safranbolu Jeoloji Haritası

Sahada kanyon vadi ve mağara gibi belirgin yer şekillerinin oluşumunda kayaçların özellikleri de önemli rol oynamıştır. Türkiye jeoloji haritası göz önüne alındığında araştırma sahasında aşınmaya uygun konglomera, kum taşı ve kireç taşı kayaçlarının yaygın olduğu görülmektedir (Türker ve Çetinkaya, 2009: 289). 
Safranbolu'da dört kanyon, bir nehir vadisi, karstik şekillere sahip bir mağara, dağlık saha ve kayalıklardan teşekkül yer şekilleri jeoturizm kapsamında değerlendirilecek coğrafi kaynakları oluşturmaktadır (Tablo 2) (Şekil 4).

Tablo 2. Safranbolu'da Jeoturizm Kapsamında Değerlendirilen Coğrafi Kaynaklar

\begin{tabular}{|c|c|c|c|}
\hline Temel Kategori & Örnek Jeositler & Temel Kategori & Örnek Jeositler \\
\hline Peyzajlar & - & Rüzgâr Yer Şekilleri & - \\
\hline Kiyılar & - & $\begin{array}{l}\text { Çökelme ile oluşan } \\
\text { Yer Şekilleri }\end{array}$ & - \\
\hline Dağ Sıraları & - & $\begin{array}{l}\text { Volkanik Yer } \\
\text { Sekilleri }\end{array}$ & - \\
\hline Kanyonlar & $\begin{array}{l}\text { İncekaya (Gayza) Köyü Tokatlı Kanyonu, } \\
\text { Düzce Köyü Düzce (Kirpe) Kanyonu, } \\
\text { Sırçalı Köyü Sırçalı Kanyonu, } \\
\text { Sakaralan Köyü Yağcı (Yaci) Kanyonu }\end{array}$ & Kaya Mostrası & - \\
\hline Nehir Vadileri & Araç Çayı Vadisi (Kadıbükü Köyü) & Fosiller & - \\
\hline Buzul Yapilar & - & Şelaleler & - \\
\hline Kumul Yapilar & - & Mağaralar & $\begin{array}{l}\text { Aşağı Dana Köyü } \\
\text { Hızar Mağarası }\end{array}$ \\
\hline Karstik Şekiller & $\begin{array}{l}\text { Aşağı Dana Köyü Hızar Mağarası Sarkıt } \\
\text { ve Dikitleri }\end{array}$ & Dağlar & Sarı Çiçek Dağı \\
\hline Volkanlar & - & Yer Şekilleri & $\begin{array}{l}\text { Aşağıdana Köyü } \\
\text { Kayalıkları }\end{array}$ \\
\hline
\end{tabular}

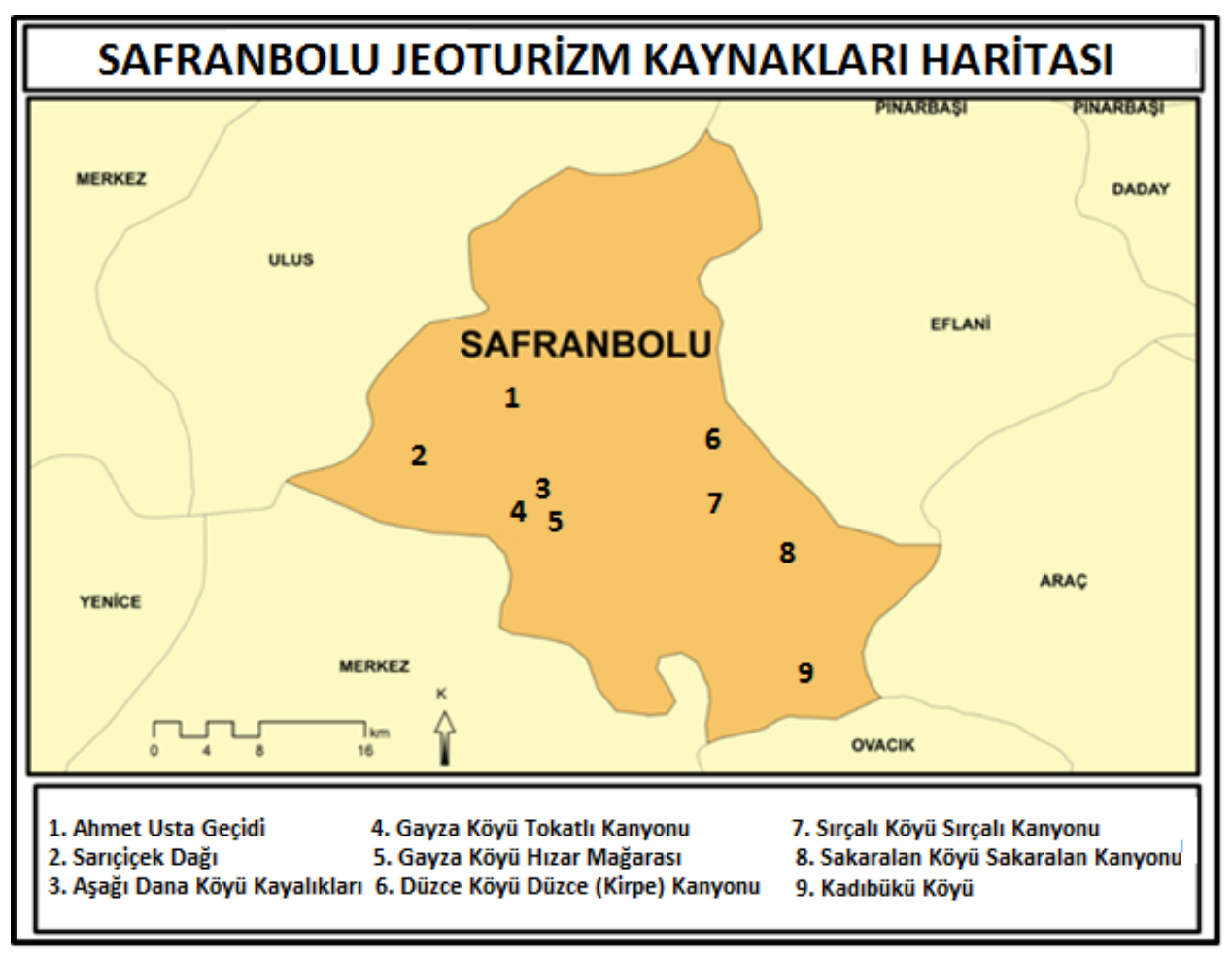

Şekil 4. Safranbolu'da Jeoturizme Yönelik Coğrafi Kaynaklar 


\section{Safranbolu'nun Jeoturizm Potansiyelinin Belirlenmesi}

Yapılan araştırma sonucunda Safranbolu'da jeoturizm kapsamında değerlendirilecek coğrafi kaynaklar ile ilgili elde edilen bulgular şu şekildedir:

\subsection{Kanyonlar}

Tablo 2'de belirtildiği üzere Safranbolu'da jeoturizm kapsaminda değerlendirilecek 4 adet kanyon yer almaktadır.

\subsection{1. İncekaya (Gayza) Köyü Tokatlı Kanyonu}

Aşağ1 Dana Köyü'nün güneyinde İncekaya (Gayza) Köyü'nden başlayan kanyon, Tokatlı Köyü'nden geçerek Eski Çarşı'ya kadar uzanmaktadır. 3. Zaman Eosen dönemine ait kireçtaşlarından oluşan tabakaların Hızar Çayı tarafından aşındırılması sonucunda oluşan kanyon, $550 \mathrm{~m}$ rakıma, 50 - $100 \mathrm{~m}$ arasında yüksekliğe ve 100 - $180 \mathrm{~m}$ arasında genişliğe sahiptir. Kanyonun uzunluğu yan kolları ile birlikte 4500 m’yi bulmaktadır (Türker ve Çetinkaya, 2009:319) (Fotoğraf 1a).

Jeolojik ve jeomorfolojik açıdan önem taşıyan Tokatlı Kanyonu, pek çok bitki (boyatan sarmaşık gibi) ve hayvan türüne de ev sahipliği yapmaktadır. Bu özellikleri ile kanyon biyolojik çeşitlilik açısından da zengindir. Kültürel açıdan ele alındığında kanyon içerisinde 1798 yılında inşa edilen İnce Kaya Su Kemeri yer almaktadır. Söz konusu su kemeri Sadrazam İzzet Mehmet Paşa tarafından "Paşa Suyu” adı verilen su kaynağının şehre taşınması amacı ile yapılmıştır. Gerek estetik gerekse de mimari ve tarihi açıdan önem taşıyan bu kemer, Gümüş semtine kadar uzanan yürüyüş parkurunun da başlangıç noktasını oluşturmaktadır. Altı kemerli yapının uzunluğu yaklaşık 120 m, genişliği 1-2 m arasında değişmekte ve yüksekliği 30 m'dir (Fotoğraf 1b). Kanyon içerisinde Tokatlı Kanyonu Yürüyüş Parkuru yer almaktadır.

\subsubsection{Düzce Köyü Düzce (Kirpe) Kanyonu}

Düzce Kanyonu, Safranbolu'ya 9 km uzaklıkta yer alan Düzce Köyü'nün kuzeyinde Sırçalı Köyü'ne bağlı Kozcağız - Sorgucuk mahallelerinin arasındaki sahadan başlamakta, Düzce Köyü'nün yaklaşık $4 \mathrm{~km}$ doğusundan geçerek güneye Konarı Köyü'ne doğru uzanmaktadır. Kanyonun orta kesiminde, Düzce Kanyonu'na, kuzeydoğu yönünden Sırçalı Kanyonu dâhil olmaktadır (1c). Bu sebeple Düzce ve Sırçalı köylerinde yaşayanlar bu kanyonları tek bir kanyon olarak kabul etmektedir. Genel itibari ile sahadaki kanyonun kuzeyi Düzce Kanyonu, güneyi ise Sırçalı Kanyonu olarak isimlendirilmektedir. Düzce Kanyonu içerisinde Kirpe Deresi akmaktadır. Bu dere güneyde Kaya Deresi'ne (yani Eflani Deresi'ne) katılarak Araç Çayı ile birleşmektedir.

Düzce Kanyonu 650 m rakımda, 50-150 m yüksekliğinde, 102-264 m arasında değişen genişlikte ve $4800 \mathrm{~m}$ uzunluktadır (Türker ve Çetinkaya, 2009: 319). Düzce Kanyonu, araştırma sahasındaki kuzey, kuzeydoğu ve güneydoğu yönlerindeki kanyonlar dizisinin bir parçasıdır. Söz konusu kanyonlar 2. Zamana (Mezozoik) ait kretase ve genel itibariyle 3. Zamana (Senozoik) ait eosen dönemlerine ait kayaçların akarsular tarafından aşındırılması sonucu oluşmuşlardır. Bu sıranın kuzey ucunda yer 
alan Düzce Kanyonu, jeoturizm potansiyeli bakımından kuzeydoğusunda yer alan Sırçalı Kanyonu ve güneydoğusundaki Sakaralan Köyü Yağcı Kanyonu ile birlikte değerlendirilmelidir.

\subsubsection{Sırçalı Köyü Sırçalı Kanyonu}

Sırçalı Kanyonu, Safranbolu'ya 19 km uzaklıkta yer alan Sırçalı Köyü'nden başlamakta, güneybatı yönünde ilerleyerek Düzce Kanyonu ile birleşip güneye Konarı Köyü'ne doğru uzanmaktadır. Sırçalı Kanyonu, 430 m - 860 m arasında yükseltide 7.4 km uzunluğa ve 210 m yüksekliğe sahiptir. 2001 yılında Yaban Hayatı Koruma Sahası ilan edilen Sırçalı Kanyonu, fauna (karaca, tilki, yaban domuzu, tavşan, ...) açısından zengindir. Kanyon yürüyüşü ve foto safari açısından uygundur (Türker ve Çetinkaya, 2009: 320) (Fotoğraf 1d).

\subsubsection{Sakaralan Köyü Yağcı (Yaci) Kanyonu}

Yağc1 Kanyonu, Safranbolu'ya 21 km uzaklıkta Kastamonu yolu üzerindeki Sakaralan Köyü'ne bağlı Yağcı Mahallesi'nden başlamakta ve batıya Konarı Köyü'ne doğru uzanmaktadır. Yağcı Kanyonu içerisinde Eflani Deresi akmaktadır. Eflani ilçesinin tepelik sahalarından kaynağını alan Eflani Deresi; Safranbolu'ya doğru ilerleyişi esnasında Pelitören Köyü'nde Ayrık Deresi, Sakaralalan Köyü'nde Bent Deresi ve Sakaralalan Köyü ile batıda Konarı Köyü arasında ise Kaya Deresi adı ile akışına devam ederek Araç Çayı ile birleşir. Yağcı Kanyonu, kanyon yürüyüşü ve foto safari açısından uygundur.

\subsection{Vadiler}

Araştırma sahasında jeoturizm kapsamında değerlendirilecek bir vadi bulunmaktadır.

\subsubsection{Araç Çayı Vadisi (Kadıbükü Köyü)}

Araç Çayı'nın etkisiyle bir vadi şeklinde oluşum içeren Kadıbükü Köyü, sahip olduğu bitki çeşitliliğinin yanı sıra Araç Çayı'nın barındırdığı balık çeşitliliği bakımından da öne çıkmaktadır. Diğer yandan, Kadbükü Köyü Yayla Mahallesi'nde bulunan irili ufaklı mağaralar topluluğu da sahanın jeolojik geçmişi adına önem taşımaktadır.

Vadi içerisinde doğal hayat süregelmektedir. Kurt, tilki ve yaban geyiği başta olmak üzere birçok vahşi hayvan türüne rastlamak mümkündür. Vadi, botanik gözlem amaçlı geziler için de uygundur.

Günümüzde yalnızca kalıntılarının görülebildiği Molla Osmanoğlu Köprüsü ise kültürel açıdan önem taşımaktadır.

\subsection{Mağaralar}

Tablo 2'de belirtildiği üzere Safranbolu'da jeoturizm kapsaminda değerlendirilecek 1 adet karstik mağara yer almaktadır. 


\subsubsection{Aşağı Dana Köyü Hızar Mağarası}

Safranbolu merkeze yaklaşık 8 km uzaklıktaki Aşağı Dana Köyü'nde bulunan Hızar Mağarası, Hızar Çayı'nın kireçtaşlarından oluşmuş sahayı aşındırması sonucunda oluşturduğu Tokatlı Kanyonu'nun başlangıç kısmında 3. Zaman Eosen dönemine ait yaşlı kireçtaşları içerisinde oluşmuştur. Sarıçiçek Dağı üzerinden de ulaşılabilen $900 \mathrm{~m}$ rakıma sahip mağara henüz tam anlamı ile keşfedilmemiş ve bu sebeple turizme açılmamıştır. Geniş bir girişi bulunan yatay gelişimli mağara bir ana koridor ve bu ana koridora bağlı iki yan koridordan meydana gelmektedir (Fotoğraf $1 \mathrm{e})$,

Yeraltı suyuna sahip mağara içerisinde yeraltı sularının kireçtaşlarını çözerek şekillendirmesi sonucunda sarkıt ve dikit gibi karstik şekiller bulunmaktadır. Yeraltı suyu, süzülerek ilerlemesi sebebi ile temizdir ve bu nedenle içme suyu olarak kullanılmaktadır. Mağara turizmi, doğa yürüyüşü ve foto safari için uygundur.

\subsection{Dağlar}

Safranbolu'da gerek jeolojik açıdan gerekse botanik ve biyolojik zenginlik açılarından öneme sahip en önemli dağ, Sarıçiçek Dağı' dır.

\subsubsection{Sarıçiçek Dağ1}

Safranbolu'nun zirvesi durumundaki Sarıçiçek Dağı, 1750 m yüksekliğe sahiptir. Şehrin kuzeybatı sınırını teşkil eden dağ, III. Zaman (Senozoik) Tersiyer devri eosen dönemine ait kayaçlardan oluşmaktadır. Dağ, orman dokusu bakımından zengindir. Çam (Pinus), Meşe (Quercus) ve Karaağaç (Ulmus) ormanlarının bulunduğu bölgede bitki örtüsü Çayır (Meadow) ağırlıklıdır. Genel itibari ile nemli soğuk orman kuşağında olmasına rağmen Akdeniz bitki topluluğuna ait defne ve sandal gibi maki elemanları da yer almaktadır. Boz Ayı, geyik, tilki ve kurt başlıca hayvan varlığını oluşturmaktadır.

\subsection{Yer Şekilleri}

Araştırma sahasında jeolojik açıdan önem arz eden yer şekilleri olarak karşımıza kayalıklar çıkmaktadır.

\subsubsection{Aşağı Danaköy Kayalıkları}

Safranbolu ilçe merkezinden ortalama 5-6 km uzaklıkta olan kayalık saha, III. Zaman (Senozoik) Tersiyer devri eosen dönemine ait kireç taşlarından meydana gelmektedir. Yaklaşık $45^{\circ}$ lik açı ile uzanan yatay tabakalardan oluşmaktadır. Bölgede değişik zamanlarda meydana gelen orojenik hareketler, kaya formlarında kırılmalara neden olmuştur. Jeolojik açıdan önem taşıyan kayalıklar, doğa yürüyüş parkurları içerisinde de değerlendirilebilir. 

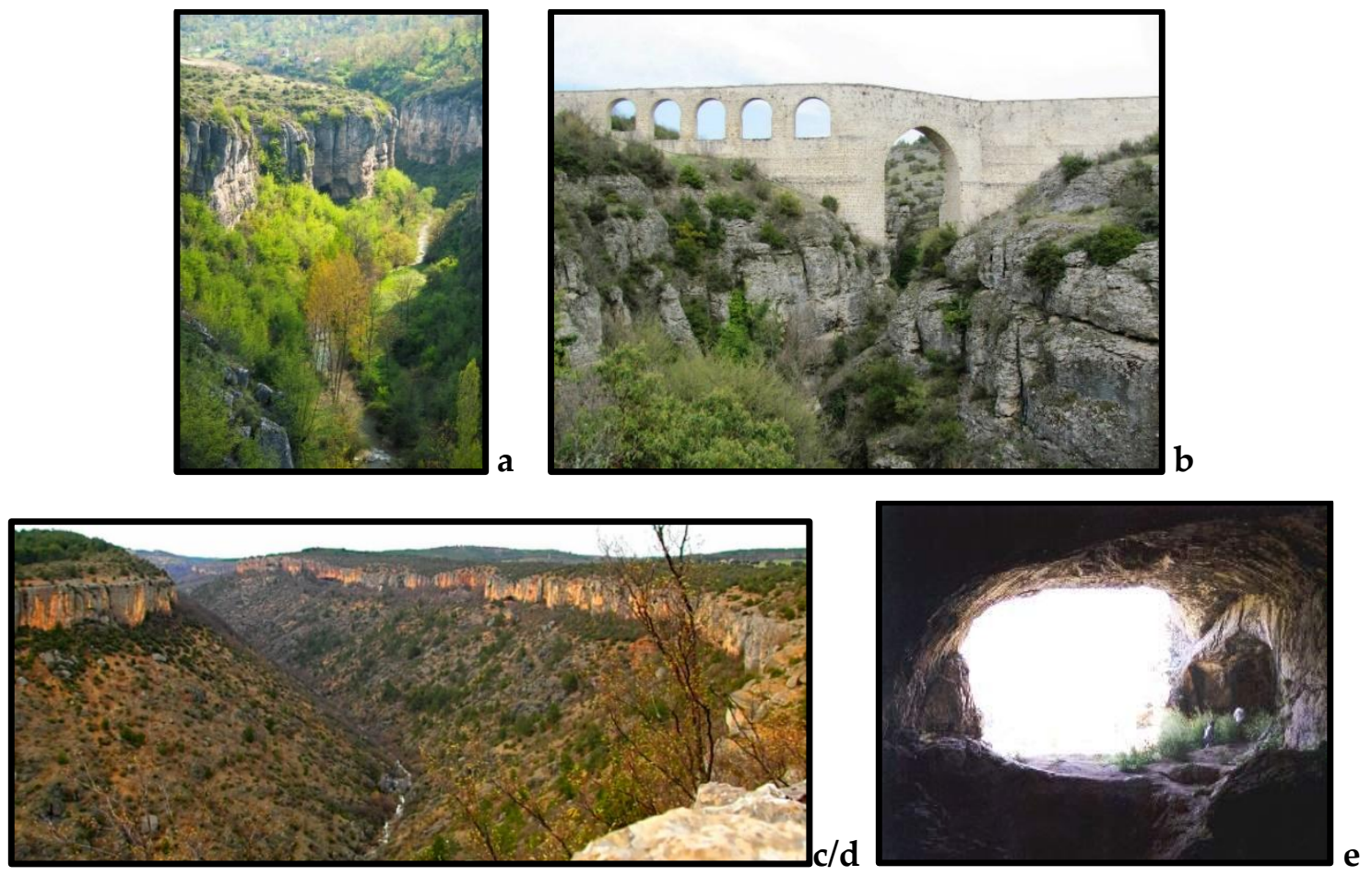

Fotoğraflar: a) Tokatlı Kanyonu b) İncekaya Su Kemeri

c) / d) Düzce / Sırçalı Kanyonu e) Hızar Mağarası

\section{SONUÇ VE ÖNERILER}

Bir bölgenin jeolojik geçmişi, o bölgenin tarihsel süreçteki gelişimi bakımından bilgiler vermenin yanı sıra bölgeye ait kültürün de bir parçası olarak karşımıza çıkmaktadır. Bir özel ilgi turizmi olarak karşımıza çıkan jeoturizmin de ana unsurlarını söz konusu jeolojik geçmişi yansıtan kaynaklar oluşturmaktadır. Jeolojik kaynaklar konusunda farkındalık yaratma, bu kaynakların korunması ile ilgili projelerin geliştirilmesi, araştırmalara dâhil edilmesi, turistik ürünün çeşitlendirilmesi ve yeni iş kollarının oluşturulması adına söz konusu kaynakların turizm faaliyetlerinde kullanılarak bölgelerde jeoturizm olgusunun geliştirilmesi destinasyonlar için önemlidir.

Kısmi olarak II. Zamanın sonu ve genel itibariyle III. Zaman içerisinde oluşumunu tamamlayan Safranbolu arazisi, jeolojik açıdan önem arz eden coğrafi kaynaklara sahiptir. Diğer yandan, söz konusu jeolojik oluşumların büyük bir çoğunluğu kültürel, doğal ve estetik birçok unsuru da bünyesinde bulundurmaktadır.

Düzce Kanyonu, Sırçalı Kanyonu ve Sakaralan Köyü Yağcı Kanyonu birbiriyle bağlantılı kanyon sırasının üç farklı kolu olmaları nedeniyle jeoturizm kapsamında jeoyol olarak değerlendirilebilir. Bunlara ilave olarak Tokatlı Kanyonu da jeoturizm için elverişlidir.

Araç Çayı Vadisi içerisinde bulunan Kadıbükü Köyü ve çevresi ise jeolojik oluşumlar ve doğal yapısı ile jeoturizm cazibesine sahip alanlardan bir diğeridir. 
İncekaya (Gayza) Köyü Hızar Mağarası ve mağara içerisindeki karstik şekiller ile Aşağı Dana Köyü kayalıkları da yer şekilleri ve jeolojik oluşumlar bakımından değerli estetik ve kültürel kaynaklardır ve Safranbolu'nun jeoturizm potansiyelini arttırmaktadır. Son olarak bölgedeki en önemli jeolojik kaynaklardan biri olan Sarıçiçek dağı doğal, kültürel, estetik gibi birçok açıdan potansiyel taşımaktadır ve jeoturizm açısından uygundur.

Araştırma sahasındaki coğrafi kaynakların uygunluğunun yanında güçlü yönlerini, fırsatlarını ve diğer hususları belirlemek adına yapılan SWOT analizi (Tablo 3) sonuçlarına göre incelendiğinde; Safranbolu'ya sınır olan Bulak Köyü'ndeki dünyaca ünlü Bulak (Mencilis) Mağarası, Bulak Deresi tarafından oluşturulan Bulak Kanyonu ve kanyon içerisindeki birçok doğal unsurun varlığı ile oluşan coğrafi zenginlik, sahanın hali hazırda bulunan turizm altyapısı, coğrafi konumunun önemli merkezlere yakınlığı ve ulaşım sorununun bulunmaması araştırıma sahasının jeoturizme uygunluğu açısından güçlü yönlerinden bazılarını oluşturmaktadır. Diğer yandan Safranbolu turizm destinasyonunda jeoturizm potansiyelinin kullanılmiyor olması bir firsat iken bu konudaki proje yetersizlikleri, yerel halkın bu turizm tipi ve jeokaynaklar konusundaki bilgi eksiklikleri ise zayıf noktaları oluşturmaktadır.

Bütün bu hususlar göz önüne alındığında; öncelikli olarak Safranbolu'da yerel yönetimin öncülügünde söz konusu jeoturizm alanların turizme kazandırılması adına master planlar oluşturulması ve uzun vadeli faaliyet planlamalarının yapılması gerekmektedir. Diğer yandan yine yerel yönetim öncülüğünde jeoyol olarak tescillenebilecek olan Düzce Kanyonu, Sırçalı Kanyonu ve Sakaralan Köyü Yağcı Kanyonu bağlantılarında gerekli teknik altyapı çalışmaları yapılarak jeoturizme kazandırılması önem arz etmektedir. Daha önce de belirtildiği üzere jeoturizm faaliyetleri jeokaynakların bulunduğu alanlardaki halkı göz ardı etmeden planlanmalıdır. Bu bağlamda ilgili kaynaklara yakın yerlerde bulunan halk gerek jeokaynaklar ve jeoçeşitlilik gerekse jeoturizm konularında bilgilendirilerek sürece dâhil edilmelidir. Safranbolu'da jeoturizm potansiyeli olan alanların tam anlamı ile belirlenmesi ve bu konu ile ilgili yatırımların artırılması önem taşıyan diğer hususlardır. Söz konusu hususlar ile ilgili yapılacak çalışmalarda yapılaşmanın kontrollü olarak gerçekleştirilmesi sağlanmalıdır. Son olarak belki de en önemli husus, jeoturizm açısından Safranbolu destinasyonun tanınırlığının sağlanmasıdır. Gelecek çalışmalarda Safranbolu destinasyonunda jeoturizm açısından potansiyel arz eden jeokaynakların; jeolojik özellikleri, yer aldıkları alanların biyolojik çeşitliliği, kültürel değerleri ve sosyolojik yapıları ile ilgili derinlemesine çalışmalar yapılarak envanterler oluşturulabilir. 
Tablo 3. Safranbolu'nun Jeoturizm Konusunda SWOT Analizi

\begin{tabular}{|c|c|}
\hline Güçlü Yönler (S) & Zayıf Yönler (W) \\
\hline $\begin{array}{l}\text { 1. Turizm destinasyonu olarak tanınırlığının } \\
\text { bulunması } \\
\text { 2. Konaklama imkânlarının yeterliliği } \\
\text { 3. Coğrafi konumu } \\
\text { 4. Ulaşım imkânlarının çeşitli olması } \\
\text { 5. Mevcut turizm altyapısı } \\
\text { 6. Farklı turizm tiplerinin gerçekleştiriliyor } \\
\text { olması } \\
\text { 7. Zengin doğal ve kültürel zenginlik } \\
\text { 8. Jeolojik çeşitlilik } \\
\text { 9. Jeoturizme uygunluk } \\
\text { 10. Batı Karadeniz bölgesinin biyolojik çeşitliliği } \\
\text { 11. Turistik ürün çeşitliliğinin bulunması } \\
\text { 12. Yerli ve yabancı turizm talebinin bulunması } \\
\text { 13. Somut kültür ve soyut kültür öğelerinin } \\
\text { çeşitliliğinin bulunması } \\
\text { 14. Tarihi önemi ve geçmişinin bulunması } \\
\text { 15. Jeoturizme uygun çevre köy ve ilçelerin } \\
\text { varlığı } \\
\text { 16. Turizme yönelik işgücünün varlı̆̆ ve } \\
\text { potansiyeli }\end{array}$ & $\begin{array}{l}\text { 17. Jeoturizm kavramının yeni oluşu } \\
\text { 18. Jeolojik çeşitlilik ve jeoturizm potansiyeli } \\
\text { konusundaki çalışmaların azlığı } \\
\text { 19. Jeoturizm potansiyeli konusundaki yeterli } \\
\text { tanıtım ve pazarlama faaliyetlerinin } \\
\text { bulunmaması } \\
\text { 20. Jeoturizm potansiyeli olan alanlara yakın } \\
\text { yerleşim yerlerinde nüfusun az olması ve bu } \\
\text { noktalarda tesis miktarının az olması } \\
\text { 21. Denetim imkânlarının az ve denetimin zor } \\
\text { olması }\end{array}$ \\
\hline
\end{tabular}

Firsatlar (O)

Tehditler (T)

22. Jeolojik yapısının farklı turizm tipleri için 30. Jeolojik çeşitliliğin bulunduğu alanlarda uygun olmasi halkın turizm bilincinin tam oturmamış olması 23. Jeoturizm arzının bölge için yeni olması ve rekabetin bulunmaması

24. Bitki örtüsü bakımından zenginlik

31. Jeoturizm kavraminin bölge turizm yatırımcıları tarafından bilinmemesi ve önemsenmemesi

25. Diğer Jeoturizm alanlarına nazaran turizm alt yapısının olması

32. Köylerden şehir merkezlerine olası göçler 26. Altyapı geliştirme adına uygun imkânların olasılığı

bulunması

27. Yerel yönetimin turizm faaliyetlerine destek vermesi

28. Doğal ve bozulmamış alanların varlığ

29. Bölgenin mevcut turizm talebi 


\section{KAYNAKÇA}

Buckley, R. (2010). 'Environmental Inputs and Outputs in Ecotourism: Geotourism with a Positive Triple Bottom Line?', Journal of Ecotourism, Vol.2, No. 1, pp. 76-82.

Dowling, K. R. (2011). ‘Geotourism's Global Growth' Geoheritage, 3, pp. 1-13.

Filho, S. R., Guerra, A., Fullen, M., Maria do Carmo, J. (2015). 'Geodiversity, Geotourism and Geoconservation: Trails in Serra da Bocania National Park, Rio de Janeiro State, Brazil', Geophysical Research Abstracts, Vol. 17, pp. 1-2.

Gray, M. (2008). 'Geodiversity: Developing the Paradigm', Proceedings of the Geologists' Association, 119, pp. 287-298.

Gümüş, E. (2008). Yeni Bir Doğa Koruma Kavramı: UNESCO Jeoparklar Çerçevesinde Çamlıdere (Ankara) Fosil Ormanı Fizibilite Çalışması, Ondokuzmayıs Üniversitesi Sosyal Bilimler Enstitüsü Coğrafya Anabilim Dalı, Yayınlanmamış Yüksek Lisans Tezi, Samsun.

Gürsay, M. S., Güneş, S. G. (2014). ‘ Jeoturizm ve Sürdürülebilirlik: Kızılcahamam- Çamlıdere Jeoparkı Örneği', Ankara Araştırmaları Dergisi, 2 (2), ss.203-215.

Heggie, W. T. (2009). Geotourism and Volcanoes: Heath HazardsFacing Tourists at Volcanic and Geothermal Destinastions, Travel Medicine and Infectious Disease, 7, pp. 257-261.

http://www.safranbolu.bel.tr/?/safranbolu/cografi-konum-94; 13.02.2016.

Karabük Valiliği. (2012), Karabük - Safranbolu Gezi Rehberi, Anıt Matbaa, Ankara.

Kızılcahamam Belediyesi. (2013), Kızılcahamam- Çamlıdere Jeoparkı Proje Kitapçı̆̆ı http://brosur.jeoparkankara.com/Jeopark/\#/0 adresinden çevrimiçi olarak 30.04.2016 tarihinde erişilmiştir.

Kim, S., Seongseop; Kim, Miju, Park; Jungwoong, Guo, Yingzhi. (2008), ' Cave Tourism: Tourists' Chraracteristics, Motivations to Visit, and the Segmentation of Their Behaviour', Asia Pasific Journal of Tourism Research, Vol. 13, No. 3, pp. 298-318.

Koçan, N. (2011). ‘Jeoturizm Planlaması ve Peyzaj Mimarlı̆̆ı Açısından Bir Değerlendirme: Kızılcahamam- Çamlıdere Jeoparkı', Ege Üniversitesi Ziraat Fakültesi Dergisi, 48 (1), ss. 47-53.

Koçan, N. (2012). ' Ekoturizm ve Sürdürülebilir Kalkınma: Kızılcahamam- Çamlıdere (Ankara) Jeopark ve Jeoturizm Projesi', Karadeniz Fen Bilimleri Dergisi,3, Vol. 2, No.6, ss.69-82.

Newsome, D., Dowling, R., Leung, Yu-Fai. (2012). ' The Nature and Management of Geotourism: A Case Study of Two Established Geotourism Destinations' Tourism Management Perspectives, Vol. 2,No. 3, pp. 19-27.

Orams, B. M. (1995). 'Towards a more desirable form of ecotourism' Tourism Management, Vol.16, No. 1, pp. 3-8.

Özdemir, Ü., Güner, İ. ve Kopar, İ. (2002). 'Safranbolu Platosu'nda Geçici Kır Yerleşmeleri', Doğu Coğrafya Dergisi, 7 / 33-152.

Stueve, M. A., Cook, D. S., Drew, D. (2002). 'The Geotourism Study: Phase I Executive Summary', National Geographic Traveler/TIA, pp. 1-22. 
Tunçözgür, Ü. (2012). Dünden Bugüne Safranbolu, Safranbolu Belediyesi Kültür Yayınları 1, Karist Baskı, İstanbul, s: 15, 16, 17, 18.

Turoğlu, H., Özdemir, H. (2005). ‘Bartın İlinin Ekoturizm Potansiyelinin Belirlenmesi’ Doğu Coğrafya Dergisi, 13, ss.97-116.

Türker, N. ve Çetinkaya, A. (2009). Batı Karadeniz Bölümü Ekoturizm Potansiyeli, Detay Yayıncılık, Ankara.

UNESCO. (2015). ‘UNESCO Küresel Jeopark Ağ1 ve Uluslararası Yerbilimleri ProgramiBidirisi',http://www.unesco.org/new/en/naturalsciences/environment/earthsciences/global-geoparks/ adresinden çevrimiçi olarak 30.04.2016 tarihinde erişilmiştir.

Yıldırım, T., Koçan, N. (2008). ' Nevşehir Acıgöl Kalderası Kalecitepe ve Acıgöl Maarlarının Jeoturizm Kapsamında Değerlendirilmesi', Ege Üniversitesi Ziraat Fakültesi Dergisi, 45 (2), ss. 135-143. 